\title{
Hotel Packages for Corporate Tourists as a Business Management Tool
}

\author{
Olga Mysova*, Tatiana Degtyaryova, Nadezhda Shcherbakova \\ Don State Technical University, Shakhty, Russia \\ ${ }^{*}$ Corresponding author. Email: eliseewa.olga@mail.ru.
}

\begin{abstract}
The purpose of the article is to determine the range of hotel services for corporate tourists as a tool for managing the hotel business in the post-image situation in Russia. In the course of the study, the authors analyze the statistics of the travel and tourism sector, determine the structure of visitors to collective accommodation facilities in Russia by purpose of arrival. The analysis of the segment of corporate tourists as consumers of the hotel services market was carried out, the share of business tourism in the world market of hotel services was determined; revealed the preferences of corporate tourists. The authors proposed a group of indicators of the impact of the development of corporate tourism for hotels, destinations and the local community. The results obtained show that it is advisable to develop new hotel products aimed at corporate tourists, which are a profitable segment and a key competitive factor in the hotel services market.
\end{abstract}

Keywords: hotel, consumer segment, business tourism, corporate guests, hotel package, business management tools.

\section{INTRODUCTION}

In 2020, accommodation facilities found themselves in a difficult situation related to the spread of the new corona virus infection, and entailed a protracted crisis. The prevailing market environment prompts the hotel business to look for effective management tools to minimize the negative impact of the pandemic. Moreover, this happens regardless of the size of the city in which the hotel is located. At the same time, the closure of borders has led to an increase in the popularity of domestic tourism in Russia, which has led to increased competition between hotels. The tourist has the opportunity to choose a hotel that will provide him with maximum comfort in the place of his temporary stay. The emergence of alternative options when choosing a hotel, as a rule, entails an increase in the level of requests and expectations of a tourist in relation to the quality and level of service, as well as the ability to fully realize the goals of travel. In this regard, the primary task of any hotel is to attract the attention of the consumer and offer him a service that can best satisfy his needs and expectations. This level of service can be ensured by creating package offers tailored to the consumer, taking into account his individual needs and requests. When choosing a accommodation facility, tourists choose, first of all, a set of services that will ensure a comfortable stay and create the most acceptable conditions for the realization of travel goals.

It is generally accepted that such a phenomenon as corporate tourism appeared in the West in the 60s of the last century, when employees of large companies independently organized travel with colleagues within their region: they rented mansions and villas, traveled in trailers and equipped vans. Over time, from an unorganized type of tourism, this direction moved into the sphere of activity of professionals, corporate tours from tour operators, specialized agencies appeared. Gradually, photographers, videographers, guides and business coaches joined the organization of the events. Interest in corporate tourism penetrated into Russia in the 90s of the XX century, it has been developing for more than 20 years, and every year the interest in corporate tourism is only growing. The pandemic caused by COVID-19 has made this type of tourism actual because in the usual sense, package tours are being transformed, safety comes to the fore in goalsetting. Accordingly, it is better to go on a trip in a group consisting of relatives, friends and acquaintances, and in the case of corporate tourism - from employees of one enterprise, and the tour program should be rich and interesting. Hotels that can personalize services 
through the integration of advanced digital technologies, their own resources and location resources can take a leading position in the hotel services market.

Awareness of this trend makes the segment of corporate tourism consumers quite attractive and profitable not only for the hotel business, but also for the destination in which the hotel is located. In connection with this issue of servicing corporate tourists, the formation of package offers for this segment is very relevant.

\section{MATERIALS AND METHODS}

According to statistics, in the structure of travel for business purposes, individual travel accounts for about $70 \%$ of the total volume of tourism, congress tourism $16-17 \%$, exhibition tourism - $10-11 \%$ and incentive tourism - $2-3 \%$.

Corporate tourism is closely related to business tourism, conference tourism, but differs from them. It includes travel by employees of one company, rather than individual travel or attending industry conferences where partners, colleagues from other firms, or competitors are present. In addition, corporate tours are dominated by goals such as team building, recreation, and not negotiations or contracts.

Hotel packages should be built taking into account the tasks that the business solves through corporate tourism:

- encouragement of employees;

- improving communication with colleagues;

- effective team building;

- training;

- rest to improve the efficiency of employees;

- reduction of fatigue and stress;

- development of corporate culture.

For the study, argumentation of conclusions and the formation of recommendations, general scientific methods of the statistical and system-functional approach and generalization, analysis and synthesis were used, as well as private methods of economic analysis - grouping, qualitative and quantitative analysis, expert assessments.

Proceedings are devoted to general theoretical issues of studying the hotel services market A. Japutra [1], T. Radojevic [2], B. Triatmantoa [3], A. Bonfanti [4], A. Beerli-Palacio [5], L.T. Tuana [6], C. Koo [7], A. Sukhua [8], O. Katerinich, T. Degtyaryova, I. Stolyar, I. Usova [9], Larionova A.A., Zaitseva N.A., Degtyaryova T.V., Mysova O.S., Nagai N.G., Oboimova N.T., Shcherbakova N.V. [10], Degtyaryova
T.V., Gusev N.I., Eliseeva O.V., Mysova O.S., Nagay N.G. [11].

Research on hotel service is reflected in the research papers of the following authors: M. Kim [12], K. Wohlfarth [13], L.Kazmina [14], N.A. Zaitseva [15], N.Y. Goryushkina [16], S. Wang [17].

The Hospitality Management Tool Study is updated with the latest WTTC Annual Survey, according to which:

The travel and tourism sector lost almost USD 4,5 trillion and reached USD 4,7 trillion in 2020, while its contribution to GDP decreased by a staggering $49,1 \%$ compared to 2019; compared to the decline of the world economy by $3,7 \%$ of GDP in 2020 .

62 million jobs were lost in 2020, an 18,5\% reduction, leaving only 272 million jobs in the industry, up from 334 million in 2019. The threat of job loss persists as many jobs are now supported by government schemes.

Domestic tourist spending decreased by $45 \%$, while foreign tourist spending decreased by an unprecedented $69,4 \%$.

The object of the research is the structure of visitors to collective accommodation facilities in Russia by purpose of stay. The time interval for this study covers 2015-2019. Statistical material for analysis is given in the table 1 .

Table 1. Structure of visitors to collective accommodation facilities in Russia by purpose of stay.

\begin{tabular}{|l|c|c|c|c|c|}
\hline \multicolumn{1}{|c|}{ Indicator } & $\mathbf{2 0 1 5}$ & $\mathbf{2 0 1 6}$ & $\mathbf{2 0 1 7}$ & $\mathbf{2 0 1 8}$ & $\mathbf{2 0 1 9}$ \\
\hline $\begin{array}{l}\text { Structure of visitors to } \\
\text { collective } \\
\text { accommodation } \\
\text { facilities by purpose } \\
\text { of stay, thousand } \\
\text { people: }\end{array}$ & 40506 & 54431 & 61536 & 71538 & 76042 \\
\hline $\begin{array}{l}\text { vacation, leisure and } \\
\text { recreation }\end{array}$ & 168 & 258 & 299 & 377 & 403 \\
\hline education and training & 131 & 166 & 212 & 252 & 304 \\
& 3 & 5 & 8 & 3 & 9 \\
\hline $\begin{array}{l}\text { medical and wellness } \\
\text { procedures }\end{array}$ & 500 & 540 & 542 & 580 & 655 \\
\hline religious / pilgrimage & 114 & 139 & 201 & 184 & 328 \\
\hline shopping and others & 510 & 333 & 332 & 384 & 415 \\
& 5 & 1 & 2 & 3 & 2 \\
\hline $\begin{array}{l}\text { business and } \\
\text { professional goals }\end{array}$ & 91 & 33 & 95 & 214 & 216 \\
\hline
\end{tabular}

Source: Rosstat.

Rostov Region and Rostov-on-Don, as the capital of the Southern Federal District, annually attract millions of tourists. Consequently, one of the main tasks of the region is to improve and create hotel services that meet the modern needs of guests of the Don region. Depending on the destination, the characteristics of the customer service categories and some other factors in the Rostov region, there are such types of accommodation facilities as: hotel, motel, hotel, guest 
house, park hotel, apart-hotel, mini-hotel, boutique hotel, hostel. Statistical information in the field of tourism in the Rostov region is presented in the table 2.

Table 2. Statistical information in the field of tourism of the Rostov region.

\begin{tabular}{|c|c|c|c|c|c|}
\hline Indicator & 2015 & 2016 & 2017 & 2018 & 2019 \\
\hline $\begin{array}{l}\text { Number of } \\
\text { collective } \\
\text { accommodatio } \\
\mathrm{n} \text { facilities, } \\
\text { units. }\end{array}$ & 362 & 399 & 441 & 503 & 500 \\
\hline $\begin{array}{l}\text { The number of } \\
\text { places in them, } \\
\text { units }\end{array}$ & $\begin{array}{c}1669 \\
6\end{array}$ & $\begin{array}{c}1746 \\
8\end{array}$ & $\begin{array}{c}1899 \\
4\end{array}$ & 21479 & 21414 \\
\hline $\begin{array}{l}\text { Number of } \\
\text { persons } \\
\text { accommodated } \\
\text { in collective } \\
\text { accommodatio } \\
\text { n facilities, } \\
\text { thousand } \\
\text { people }\end{array}$ & 755,5 & 812,0 & 962,9 & $\begin{array}{c}1151 \\
2\end{array}$ & $\begin{array}{c}1158 \\
8\end{array}$ \\
\hline
\end{tabular}

\section{RESULTS}

Based on the data in Table 1, we will analyze the dynamics of the structure of visitors to collective accommodation facilities in Russia by purpose of stay in percentage terms and for clarity, we will present it in the form of a figure 1 .

According to Table 1, the number of visitors to collective accommodation facilities for business and professional purposes in physical terms from 2015 to 2019 had a steady positive trend. However, when analyzing the structure, it was revealed that in the total population (personal goals plus business and professional goals), the dynamics was as follows: in 2015 , there were $29,85 \%$ of visitors with business and professional goals, in 2016 it was 33,13\%, which is $3,28 \%$ more than in 2015 , the indicator in 2017 was $33,3 \%$, in $2018-29,94 \%$, and in 2019 the indicator turned out to be the lowest and amounted to $28,45 \%$ of the total structure.

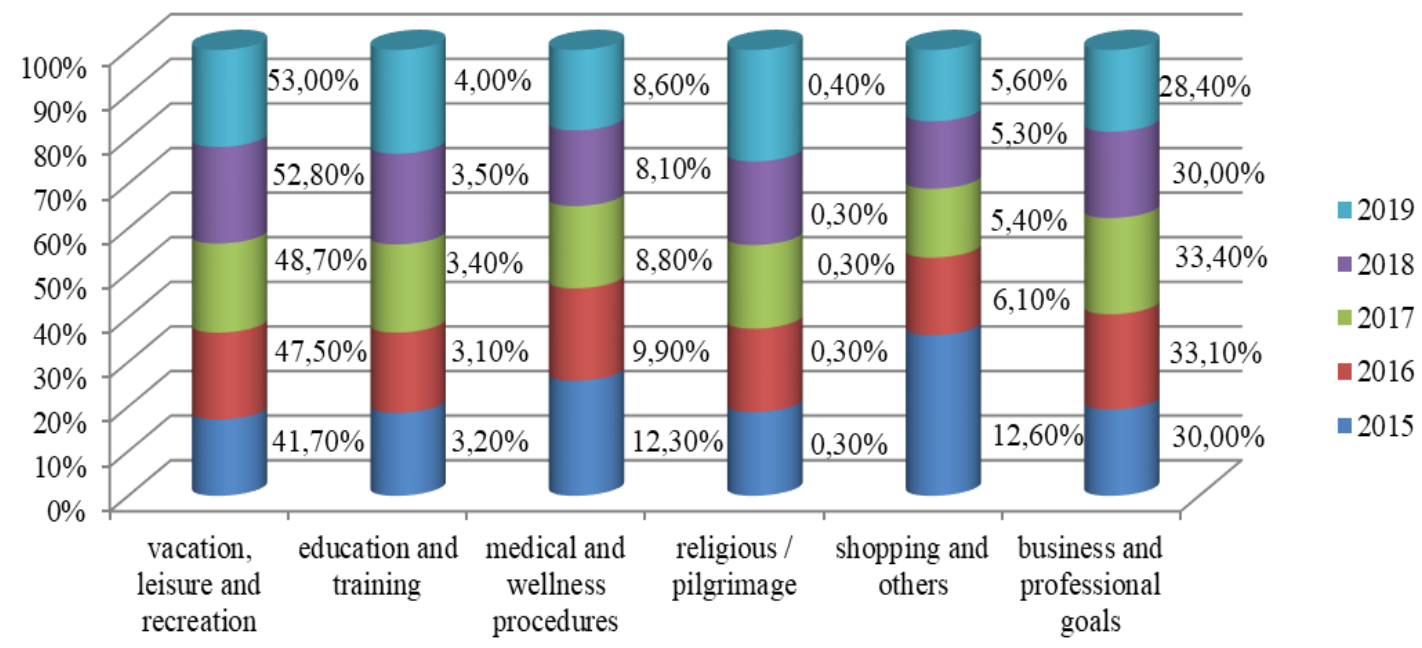

Figure 1 Dynamics of the structure of visitors to collective accommodation facilities in Russia by purpose of stay, $\%$

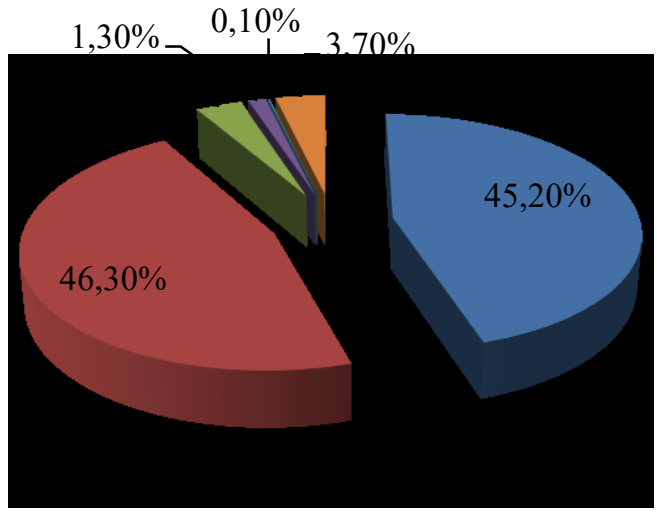

Vacation, leisure, rest

- Business and professional travel

Education, vocational training

- Healing and wellness procedures

- Religious (pilgrimage) trips

- Others

Figure 2 Structure of visitors to collective accommodation facilities in Rostov-on-Don by purpose of stay, \% (2019) 
Table 3. Indicators affecting the development of corporate tourism.

\begin{tabular}{|c|c|c|c|}
\hline $\begin{array}{l}\text { Indicator } \\
\text { group } \\
\text { name }\end{array}$ & Hotel & Destination & Local community \\
\hline $\begin{array}{l}\text { Economic } \\
\text { indicators: }\end{array}$ & $\begin{array}{l}\text { business preservation; reducing } \\
\text { losses caused by the } \\
\text { consequences of the spread of } \\
\text { COVID-19; increasing the load } \\
\text { of the room fund; increase in } \\
\text { business profitability. }\end{array}$ & $\begin{array}{l}\text { an increase in the share of revenues in the } \\
\text { regional budget (both direct and indirect, } \\
\text { obtained through the development of } \\
\text { corporate tourism); attracting investment to } \\
\text { the region; obtaining a multiplier effect due } \\
\text { to the receipt of money in related } \\
\text { industries. }\end{array}$ & $\begin{array}{l}\text { increasing the profitability of } \\
\text { the business of manufacturers } \\
\text { of local products involved in } \\
\text { hotel packages employment } \\
\text { growth due to the multiplier } \\
\text { effect. }\end{array}$ \\
\hline $\begin{array}{l}\text { Social } \\
\text { indicators: }\end{array}$ & $\begin{array}{l}\text { reduction of social tension in } \\
\text { the team caused by the } \\
\text { consequences of the spread of } \\
\text { COVID-19; preservation and } \\
\text { creation of new jobs. }\end{array}$ & $\begin{array}{l}\text { reducing social tension caused by the } \\
\text { consequences of the spread of COVID-19; } \\
\text { preservation and growth of employment of } \\
\text { the population through the creation of } \\
\text { additional and new jobs both directly in the } \\
\text { hospitality industry and in other sectors of } \\
\text { the economy associated with it. }\end{array}$ & $\begin{array}{l}\text { development of crafts, } \\
\text { creation of objects of tourist } \\
\text { interest in the form of events, } \\
\text { unique products of local } \\
\text { production; } \\
\text { reducing unemployment and } \\
\text { poverty, and most importantly } \\
\text { social tension. }\end{array}$ \\
\hline $\begin{array}{l}\text { Image and } \\
\text { promotion: }\end{array}$ & $\begin{array}{l}\text { collaboration with local } \\
\text { product manufacturers; } \\
\text { formation of new channels for } \\
\text { promoting services; } \\
\text { opportunity to become a point } \\
\text { of placement in branded routes. }\end{array}$ & $\begin{array}{l}\text { formation of a favorable image of the } \\
\text { region as a location for the organization of } \\
\text { corporate tourism; increasing brand } \\
\text { awareness of the destination; increasing the } \\
\text { status of the region as a cultural, business } \\
\text { and innovation center, attractive for } \\
\text { investment and business organization. }\end{array}$ & $\begin{array}{l}\text { the opportunity to sell local } \\
\text { products, souvenirs. }\end{array}$ \\
\hline $\begin{array}{l}\text { Contacts } \\
\text { and } \\
\text { business: }\end{array}$ & $\begin{array}{l}\text { collaboration with local } \\
\text { product manufacturers; } \\
\text { preservation and expansion of } \\
\text { the sales market for hotel } \\
\text { services. }\end{array}$ & $\begin{array}{l}\text { preservation and expansion of the quantity } \\
\text { and quality of business, cultural and trade } \\
\text { relations of the destination with other } \\
\text { regions and countries. }\end{array}$ & $\begin{array}{l}\text { collaboration with hotels; } \\
\text { preservation and expansion of } \\
\text { the market for local products; } \\
\text { preservation and expansion of } \\
\text { the sales market for } \\
\text { souvenirs. }\end{array}$ \\
\hline
\end{tabular}

According to table 2, there was a steady positive trend in the development of quantitative indicators of the market for accommodation facilities in the Rostov Region: from 2015 to 2019, the number of placed persons increased by $53,38 \%$. The structure of visitors to collective accommodation facilities in Rostov-onDon by purpose of stay in 2019 is shown in figure 2 .

Thus, if in general in Russia in 2019 28,45\% of visitors were placed for business and professional purposes, then in Rostov-on-Don this figure is $17.85 \%$ higher, which confirms our hypothesis about the expediency of using the hotel infrastructure Rostov-onDon and Rostov region for the development of corporate tourism.

If we assume that classic group package hotel services are becoming a thing of the past in the postcovid economy, then the competitiveness of the hotel, regardless of the star rating, will directly depend on the level of flexibility of its administration and the ability to quickly adapt to the situation in the market. If several decades ago the main emphasis was placed on servicing private clients, then in the post-imaginary reality corporate customers have become the most attractive, putting forward certain requirements for the level and quality of service in hotels. Thus, the range of hotel services for corporate tourists can become a tool for managing the hotel business and developing the destination. The indicators that affect the development of corporate tourism are shown in the table 3 .

Considering corporate tourists as a separate category of consumers of hotel services, it is possible to form a generalized portrait of corporate tourists. Most often, the age range for foreign corporate tourists is from 41 to 65 years old, for Russian corporate tourists this figure varies from 25 to 45 years old. The percentage of male foreign corporate tourists is $60 \%$, female - $40 \%$, but among Russian corporate tourists, the ratio of men and women is presented as $70 \%$ to $30 \%$, respectively.

Expectations of corporate tourists in relation to accommodation facilities, as a rule, consist of the following factors:

- service level;

- free Wi-Fi;

- quality food;

- comfortable rooms;

- polite staff;

- safety of services and maintenance;

- availability of additional services (business center, conference services, dry cleaning or laundry, transfer services, etc.). 
Today, post-image rehabilitation of employees is relevant, therefore, it is possible to include it in the package of health services.

Corporate tourism is characterized by a short duration of stay at the hotel. Corporate vacations for 1-2 weeks are rare, which only large companies afford, since it is expensive. In addition, hotel accommodation for more than two nights rarely meets the goals of corporate travel.

\section{DISCUSSION}

In the course of the study, it was revealed that the emergence in the business environment of new hotel packages aimed at corporate tourists, which are currently a promising segment in the hotel services market, will attract an additional segment of consumers, retain the existing segment, and acquire additional competitive advantages over hotels. competitors, take a leading position in the hotel services market. Thus, in this study, the packaging of services for corporate tourists is considered as a management tool in the hotel business. It seems appropriate to consider the application of this tool in the practical activities of hotels on the example of the Rostov region with the use of image location products.

Based on the research performed, we offer packages of hotel services for corporate tourists: leisure, business with leisure. When developing packages of hotel services for corporate tourists, we suggest focusing on local products of the Rostov region. For example, hotels can be offered a package of services for corporate tourists «Gastronomic weekend». This is a package for companies wishing to conduct team building and combine it with employees' recreation.

The package for recreation of corporate tourists «Gastronomic weekend 1» will include:

1. Accommodation for 1 night in a room of the $1 \mathrm{st}$ category.

\section{Breakfast.}

3. Team building - a culinary duel in the hotel bar with a master class from the hotel chefs using local products.

4. Interactive excursion about winemaking and wine drinking culture.

5. Tasting of Don wines.

6. Late check-out until 15.00.

7. Guarded parking.

8. Discount on the service of booking tickets $5 \%$.

9. Souvenir - an apron with a company logo.
The package «Gastronomic weekend 2» will change items 4 and 5 :

4. Interactive excursion about the Don fish.

5. Tasting of Don beer with Don fish.

The package «Gastronomic weekend 3» will change items 4 and 5:

4. Interactive excursion to the Don cheese dairies.

5. Tasting of Don cheeses.

The package «Gastronomic weekend 4 » will change items 4 and 5:

4. Interactive excursion to the Don sausage enterprises.

5. Tasting of Don sausages.

The package «Gastronomic weekend 5 » will change items 4 and 5 :

4. Interactive excursion «Donskaya cuisine».

5. Tasting of Don dishes.

Most of the companies with which hotels oriented to business tourists cooperate, book rooms only for business trips of their employees, but did not hold corporate events at the hotel. This is a loyal audience already familiar with the quality of hotel service. Each hotel has a corporate customer base accumulated over the years of working with business tourists. This way of promoting a hotel package of services for corporate tourists can be considered profitable and promising.

For hotels, packages for corporate tourists are beneficial in that they will increase the load on weekends; will help attract new corporate clients for further cooperation; get additional income from regular customers. Companies whose employees will take part in team building at the hotel can become its regular customers in the future, which is convenient for accommodation facilities aimed at business travelers

\section{CONCLUSIONS}

Summarizing the above, we can state the following: the successful operation of hotels directly depends on their ability to adapt to the desires and needs of their guests, thereby providing a high level of service; the economic difficulties caused by the COVID-19 pandemic significantly affect the hotel's activities, affecting primarily the socio-economic indicators. The prevailing market environment prompts the hotel business to look for effective strategies to minimize the negative impact of the pandemic, regardless of the size of the city in which the hotel is located. Based on these provisions, the packaging of hotel services aimed at corporate guests is the most optimal tool for accommodation facilities to get out of a crisis situation, 
since hotels whose activities are aimed at this segment of consumers have the necessary material and technical base and cooperation agreements with enterprises. The desire of companies to help employees meet emerging needs makes the development of new hotel products for corporate travelers relevant. The considered tool for managing the hotel business in a post-image situation in Russia will be very effective both for hotels and for the destination as a whole and the local community, since its use entails obtaining a multiplier effect due to the receipt of money in related industries.

\section{REFERENCES}

[1] A, Japutra, R, Situmorang, International Journal of Hospitality Management, 95 (2021) pp. 102890.

[2] T. Radojevic, N. Stanisic, N. Stanic, R. Davidson, Tourism Management, 67 (2018) pp. 326-341.

[3] B, Triatmantoa, H, Respatia, N. Wahyunib, Heliyon, 7(3) (2021) pp. e06404.

[4] A. Bonfanti, V. Vigolo, G. Yfantidou, International Journal of Hospitality Management, 94 (2021) pp. 102871 .

[5] A. Beerli-Palacio, J. D. Martín-Santana, C. RománMontoya, International Journal of Hospitality Management, 87 (2020) pp. 102458.

[6] L. TrongTuana, D. Rajendrana, Ch. Rowleyb, D. Cong Khaic, Journal of Hospitality and Tourism Management, 39 (2019) pp. 137-149.

[7] Ch. Koo, Ja. Park, J.-N. Lee, Information \& Management, 54(6) (2017) pp. 683-686.

[8] A. Sukhua, H. Choib, M. Bujisicc, A. Bilgihan, International Journal of Hospitality Management, 77 (2019) pp. 51-63.

[9] O. Katerinich, T. Degtyaryova, I. Stolyar, I. Usova, E3S Web of Conferences, 210 (2020) pp. 12003.

[10] A. A. Larionova, N. A. Zaitseva, T. V. Degtyaryova, O. S. Mysova, N. G. Nagai, N. T. Oboimova, N. V. Shcherbakova, Modern Journal of Language Teaching Methods, 8(10) (2018) pp. 630-641.

[11] T. V. Degtyaryova, N. I. Gusev, O. V. Eliseeva, O. S. Mysova, N. G. Nagay, International Journal of Economic Perspectives, 11(3) (2017) pp. 399-404.

[12] K. Minsun, R. Wesley, R. L. Seul, International Journal of Hospitality Management, 83 (2019) pp. 74-82.

[13] K. Wohlfarth, M. Klobasa, R. Gutknecht, Applied Energy, 258 (2020) pp. 114089.
[14] L. Kazmina, V. Makarenko, V. Provotorina, E. Shevchenko, E3S Web of Conferences, 210 (2020) pp. 12002.

[15] N. A. Zaitseva, I. V. Goncharova, M. E. Androsenko, International Journal of Economics and Financial Issues, 6(1) (2016) pp. 288-293.

[16] N. Y. Goryushkina, D. V. Shkurkin, A. S. Petrenko, S. Y. Demin, N. S. Yarovaya, International Review of Management and Marketing, 6(S6) (2016) pp. 207-213.

[17] S. Wang, K. Hung, International Journal of Hospitality Management, 48 (2015) pp. 92-101. 